\title{
Krige i arv
}

\section{Anders Jerichow}

\section{Afghanistan blev 11. september til amerikansk in- denrigspolitik. Irak og Iran er udenrigspolitik. Olieforsyningerne i Golfen er energipolitik. Og Israel er et stykke værdipolitik, som ingen amerikansk præsident tør lade hånt om - uanset om han hedder McCain eller Obama}

Vil man være amerikansk præsident, hører Mellemøsten med. Bush svor ganske vist, at han ikke ligesom Clinton ville spilde sin tid på håbløse mellemøstlige problemer, men - ja, resten er en sørgelig historie, og næppe nogen præsident for USA har brugt så meget tid på Mellemøsten som netop Bush.

Og vil man være Bushs afløser, gælder, at der er tre slags konflikter i Mellemøsten: De krige, man gerne vil ud af; de krige, man nødig vil ind i - og endelig de konflikter, hvor man ikke kan undslå sig for et ansvar. På den led kunne både McCain og Obama måske misunde en russisk Dmitrij Medvedev. Hvem spurgte nogen sinde Medvedev, hvordan han vil løse problemerne mellem israelere og palæstinensere? Hvordan Rusland vil sikre, at Iran ikke får en atombombe? Eller om Rusland vil bidrage til, at Afghanistan ikke igen forvandles til international lovløs vildmark - eller hjælpe Irak til at blive et retskaffent medlem af nationernes fællesskab?

De internationale forventninger til russisk lederskab er i bund. Til gengæld må en hvilken som helst amerikansk præsident tage på sig at lede, hvor andre ville foretrække at blande sig udenom.

Det vil også gælde McCain eller Obama.

En af dem arver denne vinter to krige i 'det bredere Mellemøsten', som Bush kaldte området - i Irak og Afghanistan; en truende konflikt omkring Iran og et uomgængelig amerikansk ansvar for konflikten i det såkaldt hellige land med dens evige potentiale til at eksplodere. 


\section{Den nemme konflikt}

Irak er den nemme konflikt. Så ved vi, hvor galt det kan gå i de andre brændpunkter.

Umiddelbart synes de to præsidentkandidater så forskellige som nat og dag i deres tilgang til den irakiske konflikt, som næsten har varet seks år, når McCain eller Obama overtager Det Hvide Hus, verdens stærkeste økonomi og uden konkurrence verdens stærkeste militær. McCain lover at beholde de amerikanske styrker i Irak, til konflikten er løst, om det så skal vare hundrede år. Obama lover derimod at trække USA's soldater ud i løbet af halvandet år i forventning om, at Irak kan klare sig selv.

Begge præmisser kan være forkerte: Det er ikke sikkert, at Irak kan klare sig selv om halvandet år, men det er heller ikke sikkert, at Irak nogen sinde kan klare sig selv. Alligevel synes det sikkert, at irakerne i voksende tal ønsker at tackle deres egne problemer, og at et flertal af dem allerede ser de udenlandske styrker som et problem snarere end en løsning.

Det betyder ikke, at de ønsker sig tilbage til Saddam Husseins regime før marts 2003. Men det betyder, at irakere i tiltagende grad besinder sig på at tage ansvar for deres egen stat. Et flertal af de irakiske provinser kontrolleres af irakiske sikkerhedsstyrker, når det amerikanske valg løber af stablen, og skønt al ting kan nå at gå galt i Irak i løbet af den næste præsidents valgperiode, har volden i Irak i år været faldende, og en irakisk-amerikansk aftale synes klar.

Ifølge den irakiske regering skal de amerikanske styrker i Irak 147.000 i august 2008 - være ude af Iraks byer allerede i løbet af 2009 . Og de skal være helt ude i 2011, senest 2012.

Hvis det ligefrem bliver et officielt irakisk krav, vil McCain vanskeligt kunne tale for en forlængelse, og Obama vil vanskeligt kunne tale for at trække soldaterne endnu hurtigere ud.

Men begge kan blive indhentet af det, der alt for hurtigt kan gå alt for galt. Vil irakerne fare i ny indbyrdes konflikt om fordelingen af deres oliekilder? Vil oprørske irakiske kurdere se deres snit til at kræve selvstændighed (ligesom Sydossetien og Abkhasien) og dermed fremprovokere et tyrkisk indgreb? Vil Iran fejlvurdere situationen og sende soldater ind i Irak til støtte for sine allierede i shiamuslimske militser?

Hverken en McCain eller en Obama vil være begejstret, men ingen af dem vil heller kunne ignorere Irak i sådan en tilspidsning.

\section{Problemerne i Afghanistan}

Skønt den amerikanske militære intervention i Afghanistan har FN's grønne lys og følgeskab af NATO, er Afghanistan en endnu værre hoved- 
pine. Det gik jo meget godt, firkantet sagt, i 2001, tre måneder efter alQaedas angreb på World Trade Center i New York. Den herskende Taleban-bevægelse i Kabul blev væltet af pinden og fortrængt fra byen. Samtidig blev terrorbevægelsen al-Qaeda trængt ud i bjergene. Men bagefter blev det kun kortvarigt bedre og siden tiltagende forværret. Og i modsætning til Irak er der i Afghanistan ingen statslig tradition at bygge på.

Ingen magthaver i Kabul har så længe, nogen husker i byen, haft kontrol over hele Afghanistan. Tværtimod har alle magthavere i Kabul måttet regere på grundlag af aftaler og 'forståelser' med lokale krigsherrer og klanledere ude i landet. Nogen fælles retsorden har der ikke været tale om, heller ikke et altomfatende undervisningssystem og slet ikke et velfærdssystem.

Det er galt nok i sig selv. Men hvis USA troede, at problemet i Afghanistan udsprang af Kabul, må det have været en ondartet oplevelse at erfare, at det snarere sprang over grænsen fra nabolandet, Pakistan, som forestillede at være en god amerikansk allieret.

\section{... og i Pakistan}

Og så var gode råd dyre. For i det amerikanske valgår er Pakistan blevet ramt af omsiggribende uro. Taleban- og al-Qaeda-tro klaner og militser i grænseområdet har vundet militære sejre og politisk tilslutning.
USA's mangeårige ven, diktatoren Pervez Musharraf, blev i sommeren 2008 tvunget til at trække sig. Den politiske transformation truede med kaos, og hverken en republikansk eller en demokratisk præsident i USA bryder sig om tanken, at Pakistan synker ned i kaos med både et atomvåben og Taleban inden for grænserne.

Men udviklingen i Pakistan kan blive afgørende for Afghanistans stridende politiske og etniske grupper. Og selv om McCain og Obama er enige om, at der i Afghanistan skal kæmpes til sejr, kan næppe nogen af dem regne med opbakning til at overføre 147.000 soldater fra Irak til Afghanistans morads af selvmordsbombere og vejsidebomber.

Sovjetunionen kan på et tidspunkt i 1980'erne have haft en styrke af denne størrelsesorden i Afghanis$\tan$ - men var aldrig i nærheden af en militær sejr.

Det hører godt nok ikke til international politiks grundbog, at der skulle være problemer, som ikke kan løses - eller militære fjender, som ikke kan slås ned. Men Afghanistan følger ikke de samme traditioner og regler, som amerikanere er vant til at kæmpe efter, og hvis det er rigtigt, at Medvedev og Putin ikke vil USA og Vesten det godt, ser de næppe med ubehag på, at USA og NATO nu synker ned i det samme morads, som deres egne styrker kun under store kvaler rodede sig ud af i 1989. 
Men kan tabstallene i Afghanistan blive så spektakulære, at USA og NATO ligesom Sovjet søger udgangen uden en magtfuld regering på plads i Kabul? Kan al-Qaeda genindtage sine baser i Afghanistan? Vil Taleban - med proselytter både i Afghanistan og i Pakistan - en dag vende sejrrigt tilbage, fordi bevægelsen har én ting, som USA og resten af NATO-kredsen savner, nemlig: tålmodighed?

For én ting markerer måske den synligste forskel på beslutningstagerne i NATO-kredsen og i Taleban: I NATO's hovedstæder græder man over sine døde - hos Taleban fejrer man sine martyrer.

\section{Irans bombe?}

Just mellem Irak og Afghanistan er Iran og en truende konflikt, som USA nødig vil ind i. Og igen er problemet en modspiller, som USA ikke forstår og ikke er på bølgelængde med. Hverken McCain eller Obama vil, hvis de overhovedet kan undgå det, tillade, at Iran konstruerer en atombombe og en raket, der kan bære bomben til Israel, til Golfens arabiske olielande eller for den sags skyld til Europa. Men kan USA undgå det? $\mathrm{Og}$ vil Iran tillade USA at blande sig?

Svaret på det sidste synes entydigt 'nej' - præsident Ahmadinejad og den åndelige leder, Khamenei, har indtil videre blankt afvist USA's ret til at blande sig, og jo mere USA har protesteret, des mere synes det at have sat skub i det iranske atomprojekt.

Det er et kapløb med tiden - og et kapløb om at påtage sig en ubehagelig rolle. Ingen arabisk golfstat eller Israel ville for alvor være ked af, at 'nogen' stoppede det iranske atomprojekt ved at bombe det sønder og sammen. Og det kunne for den sags skyld være sket, mens Udenrigs er i trykken. Vel, protesterne ville regne ind over FN's sikkerhedsråd, men i virkelighedens verden er det opfattelsen i både Israel og den arabiske verden, at en iransk bombe også ville starte et unødigt og dødsensfarligt atomkapløb i Mellemøsten.

Vil Bush forsøge at løse problemet eller testamentere det til McCain eller Obama? Vil de tage imod arven? Den af dem, der vinder nøglen til Det Hvide Hus, får i hvert fald ikke en mulighed for at vende ryggen til Iran. Og det er utænkeligt, at Israel skulle skride til angreb på iranske anlæg uden grønt lys i Washington.

Prisen kan blive høj. Iran truede allerede tidligt under den amerikanske valgkamp med at blokere for Hormuz-strædet, hvorigennem væsentlige dele af den frie verdens oliebehov skal udskibes. Iran truer også med angreb på Israel, på amerikanske flådestyrker i Golfen, på USA's baser i Irak - og alle andre gøremål, der kan holde en amerikansk præsident vågen. Eller give ham et telefonopkald klokken tre om morgenen. 
USA har for ikke så lang tid siden fejlvurderet en anden magthaver, som blev tillagt evnen og viljen til at bruge masseødelæggelsesvåben. Det kostede Saddam Hussein magten og senere livet. Men masseødelæggelsesvåben var der ikke i Irak. Frygten for disse våben og for diktatorens vilje til at bruge magt havde frem til 2003 tjent til at både at afskrække Saddam Husseins indenlandske og udenlandske fjender.

Og Irans atomprojekt kunne i princippet være en tilsvarende sikkerhedspolitisk Potemkin-kulisse med tilsvarende formål. Men et atomvåben kunne også være under fabrikation. Og bortset fra en pakistansk nedsmeltning, kunne USA næppe forestille sig noget værre på dé kanter end et atomvåben hos lige præcis det iranske præstestyre, som forsyner Hizbollah-bevægelsen i Libanon og radikale shiagrupper i Irak med våben, truer Israel på livet og konkurrerer strategisk med arabiske lande om magten ved Hormuz og med Pakistan om magt i Sydasien.

McCain og Obama ville utvivlsomt hellere koncentrere sig om andre spørgsmål. In their dreams.

\section{Arabisk stabilitet?}

De stigende oliepriser og USA's afhængighed af importeret olie er et $ø$ konomisk problem i sig selv. Men både den afgående præsident Bush og de to, der nu konkurrerer om at afløse ham, er enige om én ting: De anbefaler alle, at USA gør sig uafhængig af importeret olie fra det ustabile Mellemøsten.

Barack Obama lovede tilmed at gøre USA fri af mellemøstlig olie i løbet af 10 år, da han i august officielt blev nomineret til det Demokratiske Partis kandidat.

Det kan blive lettere sagt end gjort. Iran kunne i princippet true olieudskibningen fra de arabiske oliefelter udefra. Ustabilitet i de arabiske golflande kan true udskibningen indefra.

Det var Bush, der officielt gjorde fraværet af demokratisering i de arabiske lande til et potentielt problem for stabiliteten. For hans efterfølgere kan det blive et konkret problem.

Bush vovede at tale magthaverne i Saudi-Arabien imod og at kritisere Egyptens diktator på trods af USA's nervøsitet ved at skubbe til stabiliteten i de to lande.

Men Bush lagde aldrig for alvor pres på magthaverne i Riyadh eller Cairo for at få dem til at åbne og demokratisere deres samfund. Under McCain eller Obama vil både SaudiArabien og Egypten formentlig nå til et aldersmæssigt og politisk systemskifte, som kan udløse ustabilitet og udfordre USA på dets strategiske holdning til de arabiske samfunds politiske udvikling.

Supermagten vil foretrække, at de både demokratiserer og stabiliserer sig. Men det er ikke nødvendigvis et både/og - det kan blive et enten/ eller. Og hvad så, USA? 


\section{Israel er værdipolitik}

Afghanistan blev i kraft af 11. september til indenrigspolitik for enhver amerikansk præsident. Irak og Iran er udenrigspolitik. Olieforsyningerne i Golfen og trafiksikkerheden gennem Hormuz-strædet er strategisk energipolitik. Men Israel er værdipolitik af en karat, som ingen amerikansk præsident tør lade hånt om.

Helt firkantet betyder det, at ingen amerikansk præsident vil kunne tillade sig at svigte Israel, hvis det for alvor bliver truet. Det vil en amerikansk hjemmeopinon ikke tillade.

Men det betyder ikke, at amerikanske præsidenter nødvendigvis bifalder Israels politik til enhver tid. Eller at USA - uanset uenighed med Israels skiftende regeringer - vil undlade at søge en udvikling, som hindrer, at Mellemøsten eksploderer.

Allerede Carter brugte i slutningen af 1970'erne forgæves tid på at finde dén løsning, som kunne få israelere og palæstinensere til at nedlægge deres våben, og som heller ikke Clinton i 2000 og Bush nu i 2008 har kunnet finde.

Da Carter gjorde sine anstrengelser, var Israel og PLO ikke på talefod. Israel afviste at trække sig tilbage fra strategiske områder på Vestbredden og afviste tanken om en palæstinensisk stat. Clinton fik Israels Rabin og PLO's Arafat til at udveksle håndtryk ved indgåelsen af Osloaftalerne. Men Bush blev den første amerikanske præsident, som sagde lige ud, at Israel er nødt til at give plads til en palæstinensisk stat i de besatte områder, Gaza og Vestbredden. Det var ikke et øjeblik for tidligt. Spørgsmålet bliver, om det var for sent.

Under Carter var over halvdelen af de nuværende israelske bosættelser i de palæstinensiske områder endnu ikke opført. De er bygget, mens USA som Israels bedste allierede har vendt ryggen til - men også, mens den Arabiske Liga afviste at tale med israelerne om fred.

Men de israelske bosættelser er også vokset i antal og omfang, siden det arabiske topmøde i Beirut i 2002 tilbød Israel fred til gengæld for opgivelse af de besatte områder.

Og det er usikkert i dag, om nogen israelsk regering tør eller vil opgive alle eller de fleste bosættelser ligesom det er usikkert, om nogen palæstinensisk eller arabisk regering tør eller vil 'bytte' disse bosættelsesområder med anden jord fra selve Israel?

\section{Alternativet til fred}

Problemet er ikke kun palæstinensernes og israelernes. Det er også USA's. For der er kun ét alternativ til fred, og det er mere vold og ny krig mellem Israel på den ene side og palæstinensere - evt. med arabiske stater eller potentielt Iran i ryggen - på den anden.

Så længe israelere og palæstinen- 
sere blot 'nøjes med' at slå hinanden og sig selv ihjel, kan den ny amerikanske præsident i nogenlunde tryghed nøjes med at uddele gode råd og kritik efter behov. Men i det øjeblik, at en ny lokal konflikt truer med at sprede sig i Mellemøsten, begynder at udsprede terror over verden, fører til fordrivelser af palæstinensere eller dramatiske attentater mod verdens helligste steder i Jerusalem eller risikerer at provokere Iran til at blande sig, vil ingen amerikansk præsident kunne sidde på hænderne.

Hverken Carter, Clinton, Bush eller andre amerikanske præsidenter har nogensinde ønsket at stille soldater til rådighed for at føre en israelsk-arabisk fred ud i livet. De har sendt tusinder af soldater til Libanon i 1980 'erne, til Saudi-Arabien og Kuwait i 1990 og 1991, og senest til Afghanistan i 2001 og Irak siden 2003.

Alligevel er det konflikterne i og omkring Israel, som enhver amerikansk præsident er nødt til at gøre til sine egne. Også McCain eller Obama.

Anders Jerichow er kronikredaktør på Politiken og redaktør af 'Udenrigs'. 